\title{
Oral cancer patient's profile and time to treatment initiation in the public health system in Rio de Janeiro, Brazil
}

\author{
Manoela Garcia Dias da Conceição ${ }^{1} \mathbb{D}$, Isabel Cristina Martins Emmerick ${ }^{2} \mathbb{D}$, Ana Claudia Figueiró ${ }^{3} \mathbb{D}$ and \\ Vera Lucia Luiza ${ }^{4^{*}}$ (D)
}

\begin{abstract}
Background: This paper aims to describe the profile of oral cancer (OC) patients, their risk classification and identify the time between screening and treatment initiation in Rio de Janeiro Municipality.

Method: Data were obtained from the healthcare Regulation System (SISREG) regarding the period January 2013 to September 2015. Descriptive, bivariate and multivariate analysis were performed identifying the factors associates with a diagnosis of $\mathrm{OC}$ as well as the time to treatment initiation (TTI) differences between groups.

Results: From 3,862 individuals with a potential OC lesion, $6.9 \%$ had OC diagnosis. OC patients were 62.3 y.o. (mean), $64.7 \%$ male, $36.1 \%$ were white and $62.5 \%$ of the records received a red/yellow estimated risk classification. Being older, male, white and receiving a high-risk classification was associated with having an OC diagnosis. OC TTI was in average 59.1 days and median of 50 days significantly higher than non-OC individuals $(p=0.007)$. TTI was higher for individuals older than 60 years old, male, and white individuals and for risk classification red and yellow, nevertheless while in average none of these differences were statistically significant, the median of individuals classified as low risk was significantly $(p=0.044)$ lower than those with high risk.

Conclusions: Time to treatment initiation (TTI) was higher for OC patients related to non OC. Despite OC confirmed was associated with risk at screening classified as urgent or emergent, a high percentage of OC patients had their risk classified for elective care when specialized care was requested.
\end{abstract}

Keywords: Oral health, Mouth neoplasms, Primary Health Care, Specialized health care

\section{Background}

Oral health is part of general health and essential to people's well-being. Issues with oral health can have as consequences: chronic orofacial pain, cancer of the mouth and pharynx, changes in the soft tissues of the mouth, congenital disabilities, or other conditions that affect the craniofacial complex [1], leading to

\footnotetext{
* Correspondence: negritudesenior@gmail.com

${ }^{4}$ Department of Medicines and Pharmaceutical Services Policies, National School of Public Health Sergio Arouca, Oswaldo Cruz Foundation (NAF/ ENSP/FIOCUZ), 1480 Rua Leopoldo Bulhoes, Manguinhos, ZC 21041-210 Rio de Janeiro, Brazil

Full list of author information is available at the end of the article
}

psychological distress. It has been associated with alcoholism, use of tobacco products [2] and social exclusion. Among its determinants, deficient schooling, low income, unemployment, and difficulty in accessing assistance services as well as deficit in self-care are identified $[3,4]$.

According to data from the National Cancer Institute (INCA) for Brazil, in the triennium 2020-2022 there were an estimated 625 thousands new cases per year [5] and 225 thousands deaths in 2018 [6]. Almost half of the incidence of Oral Cancer (OC) occurs in the Southeast region [6], where Rio de Janeiro Municipality is located.

(C) The Author(s). 2021 Open Access This article is licensed under a Creative Commons Attribution 4.0 International License, which permits use, sharing, adaptation, distribution and reproduction in any medium or format, as long as you give appropriate credit to the original author(s) and the source, provide a link to the Creative Commons licence, and indicate if changes were made. The images or other third party material in this article are included in the article's Creative Commons licence, unless indicated otherwise in a credit line to the material. If material is not included in the article's Creative Commons licence and your intended use is not permitted by statutory regulation or exceeds the permitted use, you will need to obtain permission directly from the copyright holder. To view a copy of this licence, visit http://creativecommons.org/licenses/by/4.0/. The Creative Commons Public Domain Dedication waiver (http://creativecommons.org/publicdomain/zero/1.0/) applies to the data made available in this article, unless otherwise stated in a credit line to the data. 
Nationwide there were 11,180 OC cases in the male population and around 4010 in the female population for the 2020-2022 triennium, being the fifth most prevalent among the first [5]. Although the evolution in the prevalence estimate of $\mathrm{OC}$ is discreet, this disease is a worldwide public health problem due to its high morbidity and mortality [7].

The vulnerability of OC subjects makes it difficult to provide adequate dental care, either because of their socioeconomic status, challenges in accessing health services, or because they do not seek health services [3]. When not treated on time, it is significantly mutilating, causing damage to these patients' physical and psychological aspects and directly interfering with the quality of life [8].

However, if diagnosed early, OC has a good prognosis, with the average five-year survival rate in stages I and II being $77.3 \%$, but $32.2 \%$ in stages III and IV [9]. As an early diagnosis of OC is uncommon, with 65 to $85 \%$ of cases diagnosed in an advanced stage, the likelihood of cure is reduced [4, 10-12].

In Brazil, Primary Health Care (PHC) is supposed to have an active role regarding oral health and its actions include the promotion of oral health and prevention, care, and rehabilitation. In cases of greater complexity, it must be able to act in an articulated and swift manner with the Specialized Dental Clinics (SDCs), which corresponds to secondary care. When appropriate, such as OC diagnosis, rapid treatment initiation in a cancer center is essential. Since 2012, there is in place a federal law [12] stipulating that in the event of suspected malignant neoplasia, the diagnostic confirmation test must be carried out within 30 days after medical request and specific treatment must be started within 60 days after the positive cancer diagnosis.

The care trajectory consists of patients' path in the health care network comprising the use of health care resources from the onset of the problem to its outcome $[13,14]$. It includes making appointments in oral health, the time of return to perform referrals, performing biopsies and obtaining test results, and continuity of care after starting treatment for OC [15], which must act according to a regulation system of health care delivery. The timely care is one of the components of access to the health system. In this study, it was expressed in terms of the time to treatment initiation (TTI).

Rio de Janeiro is a 6.6 million inhabitants municipality located in Southeast region. In 2009 a comprehensive plan for PHC expansion and reorganization was implemented. In addition to a broad set of governmental health facilities comprising all levels of health care, National Institute of Cancer (INCA), the main reference center for cancer care and research in the country, is located in this city. Despite of its relevance, TTI studies are scarce in Brazil and the few [16-19] were performed in limited populations. This is the first study that evaluate time for treatment initiation in the Rio de Janeiro municipality, that considered all the susceptible population.

This study aims to describe the profile of patients with suspect and confirmed oral cancer, associated factors and time to treatment initiation (TTI) in public health system in Rio de Janeiro municipality, Brazil, from January 2013 to September 2015.

\section{Methods}

Data were obtained from the healthcare Regulation System (SISREG) regarding the period from January 2013 to September 2015. This study was part from a broader one, a $\mathrm{PhD}$ dissertation that had the general aim of evaluating the quality of the care given to patients with oral cancer $(\mathrm{OC})$ in the city of Rio de Janeiro considering the dimensions of access and effectiveness of primary and secondary health care delivery [20].

\section{Setting}

Brazil has a National Health Policy Regulation since 2008 comprising three aspects: health system, health care and access to health care, mediated by an information system. SISREG was the patient flow regulation systems used in the Brazilian Unified Health System (SUS) until 2015, when was replaced by Rio de Janeiro State Regulation System (SER) [21]. This change the data structure and storage, which made the linkage of pre and post changes complex and unworthy for the purpose of the source study. Therefore, the analysis used the complete data prior to this administrative change.

This study concerns to Rio de Janeiro municipality, a 6.6 million inhabitants (population at 2012) Brazilian City [22] and a complete health services offer, comprising all health care levels.

Oral Care counts on a regionalized and hierarchical services network, offered in PHC, secondary, high complexity and urgency / emergency health facilities [7]. Secondary OC is provided in Specialized Dental Clinics (SDC) (Centro de Especialidades Odontológicas (CEO), in Portuguese), that offer Endodontics, Periodontics, Minor surgery, Stomatology, Orthodontics and Prostheses care as well as care for patients with special needs [7]. The recommended patient flow is presented in Fig. 1.

To initiate care, patients must look for their reference PHC facility which is also supposed to offer health promotion, and disease prevention activities. In case of specialized care need, the patient must be referred to a SDC, preferably also close to his home, through SISREG. 


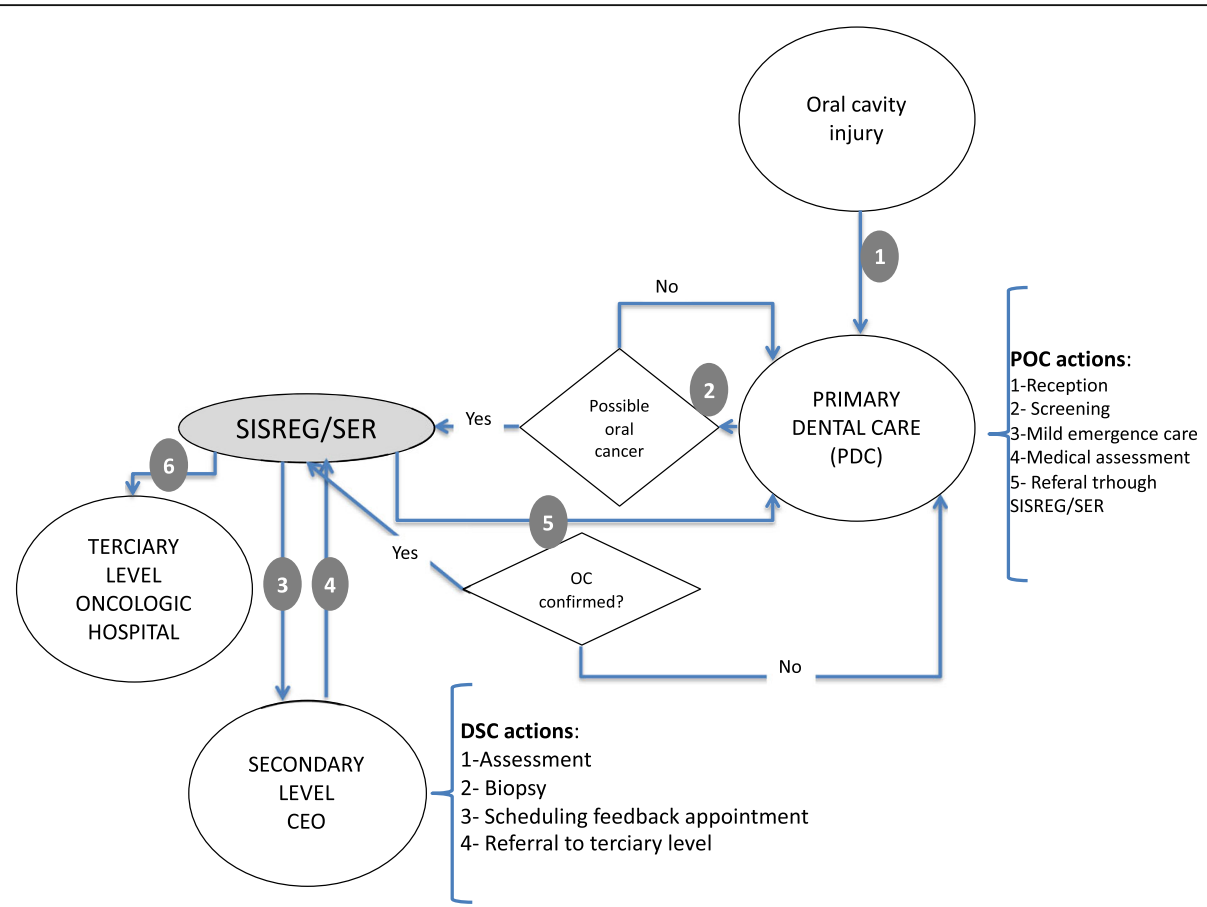

Fig. 1 Recommended flow of care for lesions suspected of oral cancer. OC = Oral Cancer; PDC = Primary Dental Care; SDC = Specialized Dental Clinics

If a more specialized care is required, e.g., cancer treatment, the patient is referred also through SISREG.

The database contained all referral records analyzed in the regulation system during the interest period by following medical specialties: general head and neck, head and neck oncology, and dentistry / stomatology.

\section{Variables}

The main outcome variable was 'having oral cancer'. The following factors were investigated: age (average and categories), excluding individuals under 15 years old; race (white vs. non-white) and first risk stratification categorized as high risk (red or yellow) and low risk (green or blue) and TTI. Risk categories are blue - elective care; green - not urgent; yellow - urgent; and red - emergent. In Brazil, the variable race is related with skin color/ethnicity and the recommendation for its collection is self-declaration by the interviewee. Despite of the name "race" have been considered obsolete in the literature, many activists argue that is important to value this variable in order to evidence disparities in the context of access to care and treatment. The time to treatment initiation was defined as the time between the first request date recorded in that database and the last execution date, what indicates the time between the first appointment and the moment that the individual was seen in his / her definitive treatment facility (start of OC treatment).

Each encounter referred was recorded in SISREG, thus the same individual can have multiple entries in the system and each record receive a risk classification. The overall risk analysis was performed by encounter. To perform the bivariate and multivariate statistical analyzes it was considered the risk evaluation attributed to the patient in the first encounter.

\section{Analysis}

For the first main outcome, the presence of oral cancer, a descriptive analysis was performed considering the distribution of age, sex and race, as well as bivariate and multivariate analysis. The difference of proportions was expressed by the odds ratio, aiming to identify differences in the demographics and risk determination between cancer and non-cancer patients.

The second outcome was the TTI, and this analysis comprised a descriptive analysis (mean and median) by presence of oral cancer diagnosis. For those with a positive diagnosis of oral cancer, it was performed the nonparametric test of median difference and T-test of the mean to verify if the TTI was different between groups by the age, sex and race. As the distribution of the variable waiting time was heterogeneous, mean and median were very different it was made the option of statistically 
test the T-test (mean) and the non-parametric tests for median differences.

All statistical analyses were performed at $95 \%$ of confidence interval using SPSS V.22.

\section{Ethical issues}

The source study was approved by three Ethical Research Committees, the first from academic institution, the National School of Public Health Sergio Arouca ERC (CAAE 59009416.6.0000.5240), the second from the National Institute of Cancer ERC (CAAE 59009416.6.3001.5274), the hospital where patients were sampled for the face-to-fac interview (data not included in this paper) and the third belonging from the Rio de Janeiro Municipality Health Secretariat ERC (CAAE 59009416.6.3002.5279).

\section{Results}

It was found a total of 3,862 individuals with a potential OC lesion in the SISREG. A total of 266 (6.9\%) individuals were confirmed as OC. The average age was 52.3 years old for those with no cancer and 62.3 years old in the $\mathrm{OC}$ group and there were no cases of oral cancer under 15 years old. Males' percentage was higher among those with $\mathrm{OC}(64.7 \%)$ and the percentage of white individuals was $36.1 \%$ and $27.5 \%$ among patients with and with no OC respectively (Table 1 ).

Table 1 Demographic characteristics by oral cancer diagnosis, SISREG. Rio de Janeiro Municipality, January 2013 to September 2015

\begin{tabular}{|c|c|c|c|c|c|c|}
\hline \multirow[t]{3}{*}{ Variables } & \multicolumn{6}{|c|}{ Oral cancer } \\
\hline & \multicolumn{2}{|c|}{ No $(N=3596)$} & \multicolumn{2}{|c|}{ Yes $(N=266)$} & \multicolumn{2}{|c|}{ Total $(N=3862)$} \\
\hline & $\mathrm{N}$ & $\%$ & $\mathbf{N}$ & $\%$ & $\mathbf{N}$ & $\%$ \\
\hline Age (mean in years) & 52.3 & & 62.3 & & 53 & \\
\hline \multicolumn{7}{|l|}{ Age (range of years) } \\
\hline$<1$ & 3 & 0.1 & 0 & - & 3 & 0.1 \\
\hline$>=1$ e $<15$ & 240 & 6.7 & 0 & - & 240 & 6.2 \\
\hline$>=15$ e $<60$ & 1820 & 50.6 & 104 & 39.1 & 1924 & 49.8 \\
\hline$>=60$ e $<85$ & 1446 & 40.2 & 151 & 56.8 & 1597 & 41.4 \\
\hline$>=85$ & 87 & 2.4 & 11 & 4.1 & 98 & 2.5 \\
\hline \multicolumn{7}{|l|}{ Sex } \\
\hline female & 2263 & 62.9 & 94 & 35.3 & 2357 & 61.0 \\
\hline male & 1333 & 37.1 & 172 & 64.7 & 1505 & 39.0 \\
\hline \multicolumn{7}{|l|}{ Race } \\
\hline asian & 425 & 11.8 & 22 & 8.3 & 447 & 11.6 \\
\hline white & 988 & 27.5 & 96 & 36.1 & 1084 & 28.1 \\
\hline indigenous & 2 & 0.1 & 0 & - & 2 & 0.1 \\
\hline brown & 771 & 21.4 & 47 & 17.7 & 818 & 21.2 \\
\hline black & 350 & 9.7 & 26 & 9.8 & 376 & 9.7 \\
\hline No information & 1060 & 29.5 & 75 & 28.2 & 1135 & 29.4 \\
\hline
\end{tabular}

From the total 4.764 records, $64.3 \%$ were classified as blue and $15.1 \%$ as red. It was found $27.2 \%$ records as red risk among the male while $9.2 \%$ among the female. Among those with OC $45.2 \%$ were classified as red risk, while this percentage was 12.9 among those with no OC. Among those records diagnosed as $\mathrm{OC}$ and risk classified as red the majority $(77.1 \%)$ were male (Table 2 ). The majority of the patients that received a diagnosis of cancer also received a red risk stratification.

The likelihood (adjusted OR) of having cancer and receiving a risk score yellow or red was 3.0 [95\%CI 2.24.3]. Males, individuals 60 years old and greater, and white were more likely to receive a diagnosis of cancer, with OR respectively of (OR 2.7 [95\%CI 2.0-3.8]). (1.8 $95 \% \mathrm{CI} \quad 1.3-2.5)$ and $(\mathrm{OR}=1.4 \quad[95 \% \mathrm{CI} \quad 1.0-1.9)$ (Table 3).

The average TTI, which is time from the first request and the appointment for those with no OC was 47.1 days and median of 23 days. Meanwhile, for patients with OC confirmed, the average TTI was 59.1 days and median of 50.5 days until being admitted in a cancer hospital and the difference was significant $(p=0.007)$ (Table 4). The TTI average was higher for individuals older than 60 years old, male, and white individuals and for risk classification red and yellow.

It was noticed that the TTI medians also followed the same patters as the means, nevertheless with greater difference. While in average none of these differences were statistically significant, the median of individuals classified as high risk was significantly $(p=0.044)$ higher than those with low risk.

\section{Discussion}

Oral Cancer (OC) had a prevalence of $6.9 \%$ in this study, with greater proportions in the older, white and males. The risk classification was the main important factor in the likelihood of having OC diagnosis. Half of the patients with oral cancer had treatment initiation within 51 days and the median of individuals classified as high risk was significantly higher than those with low risk. No gender and race disparities in terms of TTI were found.

Since 2004, with the expansion of the National Oral Health Policy (PNSB) [3], Brazil has implemented its strategies for prevention, early diagnosis, and control of OC. The PNSB implementation requires easy access to oral health services through the Family Health Strategy (ESF) and the Oral Health Teams as PHC interventions [23].

Articulated actions offered in a timely and resolutive way can prevent the late diagnosis and improve patients' prognostics. In this sense, the OC approach must include the regular screening for early detection; assessment of oral lesions (active search, home visits, 
Table 2 Distribution of estimated risk of SISREG records by selected variables by diagnosed oral cancer, SISREG. Rio de Janeiro Municipality, January 2013 to September 2015

\begin{tabular}{|c|c|c|c|c|c|c|c|c|}
\hline \multirow[t]{3}{*}{ Variable } & & & \multicolumn{4}{|c|}{ Oral cancer } & \multirow{2}{*}{\multicolumn{2}{|c|}{ Total }} \\
\hline & & & \multicolumn{2}{|l|}{ No } & \multicolumn{2}{|l|}{ Yes } & & \\
\hline & & & $\#$ & $\%$ & $\#$ & $\%$ & $\#$ & $\%$ \\
\hline Total & - & - & 4439 & 100.0 & 325 & 100.0 & 4764 & 100.0 \\
\hline \multirow[t]{4}{*}{ Estimated risk } & & BLUE - elective care & 2941 & 66.3 & 121 & 37.2 & 3062 & 64.3 \\
\hline & & GREEN - not urgent & 213 & 4.8 & 1 & 0.31 & 214 & 4.5 \\
\hline & & YELLOW - urgent & 711 & 16.0 & 56 & 17.23 & 767 & 16.1 \\
\hline & & RED - emergent & 574 & 12.9 & 147 & 45.23 & 721 & 15.1 \\
\hline \multirow[t]{8}{*}{ Sex } & BLUE - elective care & Female & 1474 & 65.4 & 47 & 46.1 & 1521 & 3.1 \\
\hline & & Male & 781 & 34.6 & 55 & 53.9 & 836 & 6.6 \\
\hline & GREEN - not urgent & Female & 133 & 71.9 & 1 & 100.0 & 134 & 0.7 \\
\hline & & Male & 52 & 28.1 & 0 & 0.0 & 52 & - \\
\hline & YELLOW - urgent & Female & 391 & 60.3 & 19 & 42.2 & 410 & 4.6 \\
\hline & & Male & 257 & 39.7 & 26 & 57.8 & 283 & 9.2 \\
\hline & RED - emergent & Female & 265 & 52.2 & 27 & 22.9 & 292 & 9.2 \\
\hline & & Male & 243 & 47.8 & 91 & 77.1 & 334 & 27.2 \\
\hline
\end{tabular}

FH Federal Hospital, SH State level hospital, UH University Hospital

specific campaigns); monitoring of suspected cases; referral services for confirmed cases; and the establishment of partnerships for prevention, diagnosis, treatment, and recovery with universities and other organizations [24].

Public health programs are expected to provide adequate responses to the health problems for which they are intended and evaluated for implementation, access, and outcomes, guiding decisionmaking [25]. Thus, it is worth asking about the offer of oral health care within the scope of the PNSB in primary, secondary and specialized health services and how patients have covered the services they need.

There is a higher likelihood of receiving a diagnosis of OC for individuals over 60 years old, males, white, which corroborates with results of other studies regarding the profile of patients and location of lesions [26, 27].

When OC diagnosed patients were referred through the SISREG system, the average time to start cancer treatment (average of 50 days and median of 59 days) is within the federal legal time period of 60 days [28]. Nevertheless, the Rio de Janeiro municipality health regulation has a more restrictive TTI rule that

Table 3 Study population demographic characteristics associated with the oral cancer diagnosis, SISREG. Rio de Janeiro Municipality, January 2013 to September 2015

\begin{tabular}{|c|c|c|c|c|c|c|}
\hline \multicolumn{2}{|c|}{ Variables (dummy) } & \multicolumn{2}{|c|}{$\begin{array}{l}\text { Cancer Oral } \\
\text { \# (percentage within Cancer Oral) }\end{array}$} & \multirow[t]{2}{*}{ Total } & \multirow{2}{*}{$\begin{array}{l}P \text {-value } \\
\text { Gross OR } \\
(95 \% \mathrm{Cl})\end{array}$} & \multirow{2}{*}{$\begin{array}{l}P \text {-value } \\
\text { Adjusted } \\
\text { OR }(95 \% \mathrm{Cl})\end{array}$} \\
\hline & & No & Yes & & & \\
\hline \multirow[t]{2}{*}{ Risk } & Blue or Green & $2440(67.9 \%)$ & 103 (38.7\%) & $2543(65.8 \%)$ & $p=0.000$ & $p=0.000$ \\
\hline & Yellow or Red & 1156 (32.1\%) & $163(61.3 \%)$ & 1319 (34.2 \%) & $3.3(2.6-4.3)$ & $3.0(2.2-4.0)$ \\
\hline \multicolumn{2}{|l|}{ Total } & 3596 (100.0\%) & $266(100.0 \%)$ & 3862 (100.0 \%) & & \\
\hline \multirow[t]{2}{*}{ Sex } & Female & $2263(62.9 \%)$ & $94(35.3 \%)$ & 2357 (61.0\%) & $p=0.000$ & $p=0.000$ \\
\hline & Male & 1333 (37.1\%) & $172(64.7 \%)$ & 1505 (39.0\%) & $3.1(2.4-4.0)$ & $2.7(2.0-3.8)$ \\
\hline \multicolumn{2}{|l|}{ Total } & 3596 (100.0\%) & 266 (100.0\%) & 3862 (100.0\%) & & \\
\hline \multirow[t]{2}{*}{ Age } & $>=15 \mathrm{e}<60$ & $1820_{a}(54.3 \%)$ & 104 (39.1\%) & 1924 (53.2\%) & $p=0.000$ & $p=0.000$ \\
\hline & $>=60$ & $1533_{a}(45.7 \%)$ & $162(60.9 \%)$ & 1695 (46.8\%) & $1.8(1.4-2.4)$ & $1.8(1.3-2.5)$ \\
\hline \multicolumn{2}{|l|}{ Total } & 3353 (100.0\%) & 266 (100.0\%) & 3619 (100.0\%) & & \\
\hline \multirow[t]{2}{*}{ Race } & Not white & $1548(61.0 \%)$ & 95 (49.7\%) & $1643(60.2 \%)$ & $p=0.003$ & $p=0.050$ \\
\hline & white & 988 (39.0\%) & 96 (50.3\%) & 1084 (39.8 \%) & $1.6(1.6-2.2)$ & $1.4(1.0-1.9)$ \\
\hline \multicolumn{2}{|l|}{ Total } & $2536(100.0 \%)$ & 191 (100.0\%) & 2727 (100.0\%) & & \\
\hline
\end{tabular}


Table 4 Mean and median of time to treatment initiation by diagnosed oral cancer, age, sex, race and risk, SISREG. Rio de Janeiro Municipality, January 2013 to September 2015

\begin{tabular}{|c|c|c|c|c|c|c|}
\hline Variables & $\mathbf{N}$ & Mean & SD & $P$-value & Median & $P$-value \\
\hline Non-Oral Cancer & 3596 & 47,1 & 70,7 & 0,007 & 23,0 & 0,000 \\
\hline Oral Cancer & 266 & 59,1 & 60,7 & & 50,5 & \\
\hline \multicolumn{7}{|l|}{ Age Group } \\
\hline$>=15$ e $<60$ & 104 & 53,8 & 53,3 & 0,254 & 39,0 & 0,379 \\
\hline$>=60$ & 162 & 62,5 & 64,9 & & 56,5 & \\
\hline \multicolumn{7}{|l|}{ Race } \\
\hline Non-white & 95 & 59,3 & 60,1 & 0,405 & 46,0 & 0,168 \\
\hline White & 96 & 67,3 & 72,1 & & 61,5 & \\
\hline \multicolumn{7}{|l|}{ Sex } \\
\hline Male & 172 & 62,0 & 59,6 & 0,294 & 56,0 & 0,158 \\
\hline Female & 94 & 53,8 & 62,6 & & 35,5 & \\
\hline \multicolumn{7}{|l|}{ Risk } \\
\hline Blue or Green & 103 & 56,4 & 77,4 & 0,571 & 31,0 & 0,044 \\
\hline Yellow or Red & 163 & 60,8 & 47,4 & & 56,0 & \\
\hline
\end{tabular}

Statistically significant $p$-values $95 \%$ confidence interval are indicated in bold

establishes that patients diagnosed with cancer must be referred by PHC, via SISREG, for specialized care. Other studies that evaluated TTI in Brazil found it as 1-3 months [18], 23 days mean (1-116 days range) [17] and 71.1 days (1-142 days range) [19]. Nevertheless, they all used small hospital-based samples. A study from INCA found a TTI below 60 days $43.8 \%$ and 56.2 for male and female patients, respectively in the Southeast Region [29]. Studies carried out in foreign countries found an average TTI of 30 days [30] and greater than 46 days [31] for $25 \%$ of treated patients, a time considered worrying for the disease outcome.

When his risk is classified as high (red), this requires priority scheduling of up to 30 days. Yellow, scheduling up to 90 days, green and blue, scheduling up to 180 days or more, respectively, was found not to adhere [32]. As well established in the literature, the TTI can be decisive for the progress and incurability of the disease [33, 34], and preventable delays should be avoided.

Among the causes for the time elapsed between the first registration of the patient in the regulation system and the beginning of treatment, one can assume the flow instituted by the health system since the PHC. For cases registered as having the highest risk for OC (red and yellow risk), the time to start treatment was longer than for the others. Serra et al. also found an inadequate organization of referral and counter-referral activities, with many of the patients not being referred by the official system, which produces double entry into the sector, resulting in losses or delays in some visits [35]. The opposite, such as decentralization and regionalization of assistance for cancer treatment, facilitate patient access, with an increase in the number of hospitalizations in some locations [36].

Another relevant factor is the difficulty in identifying a suspected lesion of these tumors, being most often diagnosed when its size exceeds $2 \mathrm{~cm}$ [37]. This situation and other factors can lead to a delay in diagnosis, as indicated by Costa-Jr and Serra [28]: few and nonspecific symptoms, patients' lack of knowledge about the disease, little familiarity of general practitioners who work in primary care with the diagnosis of cancer and difficulty in accessing the health system [38]. The late diagnosis is reflected in the most frequent treatments at the referral hospital, radiation therapy associated with surgery, knowing that the best prognosis is referred to as only surgical treatment [38].

As limitations it is important to mention that the regulation system does not include staging and other clinical information that would be helpful and could support and inform policy changes needed in the regulation and referral. Also, the SISREG is a secondary database and as such, can contain misclassifications of cases. Finally, only registered individuals that had their treatment through SUS were analyzed.

\section{Conclusions}

In this study, it was found that being male, white, and older than 60 increased the likelihood of having a diagnosis of oral cancer. The time to initial treatment was higher for those with confirmed OC diagnosis; nevertheless, TTI is within the time expectation established by Law in the National Health System and there were no disparities regarding age, race and gender. The risk classification system seems to not be a factor for speeding up the treatment, furthermore the median TTI of individuals with high-risk classification was higher and reasons for that should be clarified in future studies.

\section{Abbreviations \\ Cl: Confidence Interval; ERC: Ethical Research Committee; ESF: Family Health Strategy; INCA: National Cancer Institute; OC: oral cancer; OR: Odds Ratio; p: p value; PHC: Primary Health Care; PNSB: National Oral Health Policy; SDC: Specialized Dental Clinics (Centro de Especialidades Odontológicas - CEO, in Portuguese); SER: Rio de Janeiro State Regulation System; \\ SISREG: healthcare Regulation System; SUS: Unified Health System; TTI: time to treatment initiation; y.o.: years old}

\section{Authors' contributions}

MGD, ICME, ACF and VLL are the guarantors of the paper and takes responsibility for the integrity of the work as a whole. MGDC was responsible for obtention of the dataset. ICME was responsible for the data analysis. All authors were responsible for the study design, interpretation results, writing, and revisions and approved the submitted version.

Funding

This study had no funding. 


\section{Availability of data and materials}

The datasets generated and/or analyzed during the current study is not publicly available due to its sensitive information (PHI) Protected Health Information and sharing is not allowed by the owner, but are available from the corresponding author on reasonable request.

\section{Ethics approval and consent to participate}

The source study was approved by three Research Ethical Committees, the first from academic institution, the National School of Public Health Sergio Arouca ERC (CAAE 59009416.6.0000.5240), the second from the National Institute of Cancer ERC (CAAE 59009416.6.3001.5274), the hospital where patients were sampled for the face-to-fac interview (data not included in this paper) and the third belonging from the Rio de Janeiro Municipality Health Secretariat ERC (CAAE 59009416.6.3002.5279). Nevertheless, we use secondary data for this current manuscript and an informed consent is not applicable.

\section{Consent for publication}

Not applicable.

\section{Competing interests}

Authors have no competing interests.

\section{Author details}

'Public health Post-Graduation Program National School of Public Health Sergio Arouca, Oswaldo Cruz Foundation (PPGSP/ENSP/FIOCUZ), 1480 Rua Leopoldo Bulhoes, Manguinhos, RJ, ZC 21041-210 Rio de Janeiro, Brazil. ${ }^{2}$ Division of Thoracic Surgery, Department of Surgery, UMass Memorial Healthcare/University of Massachusetts Medical School, 67 Belmont Street \#201, Massachusetts 01605 Worcester, USA. ${ }^{3}$ Department of Collective Health, Instituto Aggeu Magalhães Institute, Oswaldo Cruz Foundation (SDC/IAM) Fiocruz), Campus da UFPE - Av. Prof. Moraes Rego, s/n - Cidade Universitária, Recife - PE, ZC 50670-420 Recife, Brazil. ${ }^{4}$ Department of Medicines and Pharmaceutical Services Policies, National School of Public Health Sergio Arouca, Oswaldo Cruz Foundation (NAF/ENSP/FIOCUZ), 1480 Rua Leopoldo Bulhoes, Manguinhos, ZC 21041-210 Rio de Janeiro, Brazil.

Received: 7 August 2020 Accepted: 28 January 2021

\section{Published online: 15 February 2021}

\section{References}

1. World Health Organization. The world oral health report 2003. Continuous improvement of oral health in the 21st century-the approch of the $\mathrm{WHO}$ Global Oral Health Programme. 2003.

2. Kowalski, LPaulo. Brentani MMitzi, Coelho FRGualda. Bases da oncologia. São Paulo: Lemar; 2003.

3. Amorim, ngc, sousa, as, alves, sm. Prevenção e diagnóstico precoce do câncer bucal: uma revisão de literatura. Rev uningá. junho de 2019;56(2):70-84

4. Narvai PC, Frazão P. Saúde Bucal no Brasil muito além do céu da boca. Rio de Janeiro: Fiocruz; 2008. 148 p.

5. Brasil Ministério da Saúde. Estimativa 2020: incidencia de cancer no Brasil. Rio de Janeiro: INCa - Instituto Nacional do Câncer; 2019. Disponível em: https:// www.inca.gov.br/sites/ufu.sti.inca.local/files//media/document//estimativa-202 0-incidencia-de-cancer-no-brasil.pdf. [citado 4 de agosto de 2020].

6. Brasil. Instituto Nacional de Câncer - INCa. Estatísticas de câncer. INCA Instituto Nacional de Câncer. 2018. Disponível em: https://www.inca.gov.br/ numeros-de-cancer. [citado 4 de agosto de 2020].

7. Brasil Ministério da Saúde. Ministério da Saúde: departamento de atenção básica. Brasil Sorridente. 2018. Disponível em: http://dab.saude.gov.br/ portaldab/ape brasil_sorridente.php. [citado 4 de abril de 2018]

8. Barbosa MBAlves. Ações de enfermagem para o controle do câncer: uma proposta de integração ensino-serviço. Rio de Janeiro (RJ): INCA; 2008.

9. Carvalho AL, Singh B, Spiro RH, Kowalski LP, Shah JP. Cancer of the oral cavity: a comparison between institutions in a developing and a developed nation. janeiro de. 2004:26(1):31-8.

10 da Silva MC, Marques EB, Melo L, de Bernardo C, de Leite JMP. Fatores relacionados ao atraso no diagnóstico de câncer de boca e orofaringe em Juiz de Fora/MG. Rev Bras Cancer. 2009;55(4):329-35.

11. Ramos GHA, Oliveira BV de, Biasi LJ, Sampaio Júnior LA. Avaliação da citologia e do teste do azul de toluidina no diagnóstico dos tumores malignos da mucosa oral. Rev Bras Cir Cabeça Pescoço 03PY - 2007 de. 2007;36(1):27-9
12. Brasil. Presidência da República. Lei $N^{\circ}$ 12.732, de 22 de novembro de 2012. Dispõe sobre o primeiro tratamento de paciente com neoplasia maligna comprovada e estabelece prazo para seu início. 2012. Disponível em: http:// www.planalto.gov.br/ccivil_03/_ato2011-2014/2012/lei/l12732.htm.

13. Figueró AC, Hartz ZMA, Brito CAA, Samico I, Filha NTS, Cazarin G, et al Óbito por dengue como evento sentinela para avaliação da qualidade da assistência: estudo de caso em dois municípios da região Nordeste, Brasil, 2008. Cad Saude Publica. 2011;12(27).

14. Gerhardt TE, Rotoli A, Riquinho DL. Itinerários terapêuticos de pacientes com câncer: encontros e desencontros da Atenção Básica à alta complexidade nas redes de cuidado. In: Atenção Básica e Integralidade: contribuições para estudos de práticas avaliativas em saúde. Rio de Janeiro: CEPESC-IMS/UERJ-ABRASCO; 2008. pp. 197-214.

15. Frias PG de, Costa JMB da Figueró $S$, Mendes AC, MF de M, Vidal SA. Atributos da qualidade.. In: Avaliação em saúde-bases conceituais e operacionais. Rio de Janeiro: Medbook; 2010. p. 43-55.

16 de Lucena EHG, da Silva RO, de Lucena CDRX, Mepatia Al, Cavalcanti YW, de Goes PSA, et al. Factors associated with conducting planning for secondary oral health care services in Brazil. BMC Health Serv Res. 2020; 20(1):853.

17. Santos V, de CB dos, Assis AMA de, Silva LE da, Ferreira SMS, Dias EP. Câncer de boca: análise do tempo decorrido da detecção ao início do tratamento em centro de Oncologia de Maceió. Rev Bras Odontol.2012;69(2):159-64.

18. Santos LCO dos, Batista O, de M, Cangussu MCT. Caracterização do diagnóstico tardio do câncer de boca no estado de Alagoas. Braz J Otorhinolaryngol.2010;76(4):416-22

19. Le Campion ACOV, Santos K, de CB dos, Carmo ES do, Silva Júnior FF da, Peixoto FB, Ribeiro CMB, et al. Caracterização do atraso no diagnóstico do câncer de boca e orofaringe em dois centros de referência. Cad Saúde Coletiva. junho de 2016;24(2):178-84

20. Dias MG. Avaliação da Atenção em Saúde Bucal: contribuições para o controle do câncer de boca no município do Rio de Janeiro [PhD in Public Health]. [Rio de Janeiro]: Escola Nacional de Saúde Pública Sergio Arouca. Fundação Oswaldo Cruz; 2018 . Disponível em: https://www.arca.fiocruz.br/ handle/icict/30885. [citado 30 de julho de 2020]

21. Peiter CC, Lanzoni GM, de M, Oliveira WF de. Universidade Federal de Santa Catarina, Brazil, Universidade Federal de Santa Catarina, Brazil, Universidade Federal de Santa Catarina, Brazil. Regulação em saúde e promoção da equidade: - Sistema Nacional de Regulação e o acesso à assistência em um município de grande porte. Saúde Em Debate dezembro de. 2016:40(111):63-73.

22. Rio de Janeiro. Prefeiruta. Plano de governo 2013-2016. Prefeitura do Rio de Janeiro; 2013.

23. Silva AN da, Senna MAA de, Jorge RC. Organização da oferta de serviços de saúde bucal no âmbito so Sistema Único de Saúde. In: Fundamentos em Saúde Bucal Coletiva. Rio de Janeiro: Medbook; 2013. p. 145-53.

24. Ministério da Saúde. Diretrizes Da Política Nacional De Saúde Bucal. 2004.

25. Champagne F, Contandriopoulos A-P, Brouselle A, Hartz ZM, de A, Denis. J-L. A avaliação no Campo da Saúde: conceitos e métodos. In: Brouselle A, Champagne F, Contandriopoulos A-P, Hartz ZM de. A, organizadores. Avaliação: conceitos e métodos. Rio de Janeiro: Editora Fiocruz; 2013. pp. 41-60.

26. Melo L, de C, Silva MC da, Bernardo JM, de P, Marques, Leite EB ICG. Perfil epidemiológico de casos incidentes de câncer de boca e faringe. RGO. 09PY - 2010 de 2010;58(3):351-5.

27. Volkweis MR, Blois MC, Zanin R, Zamboni R. V14N2 Perfil Epidemiológico dos Pacientes com Câncer Bucal em um CEO. 2014;8.

28. Subchefia para Assuntos Jurídicos. Dispõe sobre o primeiro tratamento de paciente com neoplasia maligna comprovada e estabelece prazo para seu início. 12.732 nov 22, 2012

29. Brasil. Instituto Nacional de Câncer - INCa. Intervalo de tempo entre o diagnóstico e o início do tratamento oncológico dos casos de câncer de lábio e cavidade oral [Internet]. Rio de Janeiro; 2020 nov [citado 19 de dezembro de 2020] p. 13. Disponível em: https://www.inca.gov.br/sites/ufu. sti.inca.local/files//media/document//relatorio-cancer-de-boca-2020.pdf.

30. Tsai W-C, Kung P-T, Wang Y-H, Huang K-H, Liu S-A. Influence of time interval from diagnosis to treatment on survival for oral cavity cancer: A nationwide cohort study. PLoS ONE. 2017;12(4). Disponível em: https://www.ncbi.nlm. nih.gov/pmc/articles/PMC5384671/. [citado 19 de dezembro de 2020]

31 Murphy CT, Galloway TJ, Handorf EA, Egleston BL, Wang LS, Mehra R, et al. Survival Impact of Increasing Time to Treatment Initiation for Patients With Head and Neck Cancer in the United States. J Clin Oncol. 2016;34(2):169-78. 
32. Secretaria Municipal de Saúde. SISREG - Protocolo para o Regulador. Protocolo Clínico de Critérios para Regulação de Vagas Ambulatoriais. 2014.

33. Lopez-Cedrún JL, Otero-Rico A, Vázquez-Mahía I, Seoane J, García-Caballero $\mathrm{L}$, Seoane-Romero JM, et al. Association between hospital interval and survival in patients with oral cancer: A waiting time paradox. PLOS ONE. 2019;14(10). Disponível em: https://www.ncbi.nlm.nih.gov/pmc/articles/ PMC6814211/. [citado 4 de agosto de 2020]

34. Paul C, Carey M, Anderson A, Mackenzie L, Sanson-Fisher R, Courtney R, et al. Cancer patients' concerns regarding access to cancer care: perceived impact of waiting times along the diagnosis and treatment journey. Eur J Cancer Care (Engl) maio de. 2012;21(3):321-9.

35. Serra CG, Rodrigues PH de A. Avaliação da referência e contrarreferência no Programa Saúde da Família na Região Metropolitana do Rio de Janeiro (RJ, Brasil). Ciência \& Saúde Coletiva,. 2010;15(3):3579-86.

36. Carroll CB, Gomide M. Análise de redes na regulação do tratamento do câncer do aparelho digestivo. Cad Saúde Pública. 2020;1(36).

37. World Health Organization. The world oral health report 2003. Continuous improvement of oral health in the 21st century-the approach of the WHO Global Oral Health Programme. 2003.

38. Júnior S, da C, Serra CG. Programa Saúde da Família. Cuidados com o câncer bucal. A experiência de Resende, no Estado do Rio de Janeiro. 1st. São Paulo: Napoleão; 2012. 123 p.

\section{Publisher's Note}

Springer Nature remains neutral with regard to jurisdictional claims in published maps and institutional affiliations.

Ready to submit your research? Choose BMC and benefit from:

- fast, convenient online submission

- thorough peer review by experienced researchers in your field

- rapid publication on acceptance

- support for research data, including large and complex data types

- gold Open Access which fosters wider collaboration and increased citations

- maximum visibility for your research: over $100 \mathrm{M}$ website views per year

At $\mathrm{BMC}$, research is always in progress.

Learn more biomedcentral.com/submissions 